\title{
Immunophenotypic differences between neoplastic and non-neoplastic androgen-producing cells containing and lacking Reinke crystals
}

\author{
Hector Mesa ${ }^{1,2}$ (D) - Scott Gilles ${ }^{3} \cdot$ Milton W. Datta $^{3,4} \cdot$ Paari Murugan $^{3}$. \\ Wendy Larson $^{1} \cdot$ Susan Dachel $^{1} \cdot$ Carlos Manivel $^{1,3}$
}

Received: 2 August 2016/Revised: 7 September 2016 / Accepted: 21 September 2016 /Published online: 1 October 2016

(C) Springer-Verlag Berlin Heidelberg 2016

\begin{abstract}
We performed a detailed morphologic, immunophenotypic, and endocrine characterization of neoplastic and non-neoplastic lesions of androgen-producing cells known to harbor or lack Reinke crystals (RCs) with an aim to provide further insight into the nature of these cells and crystals. Study cases were selected from the files of participating hospitals and subclassified according to current classifications: 20 with Leydig cell tumors (LCTs), 2 with testicular adrenal rest tumors (TARTs), 2 with testicular tumors of adrenogenital syndrome (TTAGS), and 2 with androgen insensitivity syndrome (AIS). An extensive immunophenotypic panel including markers used in sex cord-stromal cell tumors, androgen hormones, enzymes, and receptors was applied to the cases and 10 non-tumoral adrenal glands. Non-tumoral tissues were scored separately. RCs were present in $90 \%$ of LCT cases and all cases with normal Leydig cells; RCs stained specifically with calretinin and $3 \beta$-hydroxysteroid dehydrogenase (3BHSD) and were present only in cells with high concomitant expression of both proteins, a phenotype unique to Leydig cells and LCTs. Leydig cells from AIS cases lack
\end{abstract}

Hector Mesa

Hector.Mesa@va.gov

1 Department of Pathology and Laboratory Medicine, Veterans Administration Health Care System, One Veterans Drive, Minneapolis, MN 55417, USA

2 Minneapolis VA Health Care System, Office BB-104, One Veterans Drive, Minneapolis, MN 55417, USA

3 Department of Pathology and Laboratory Medicine, University of Minnesota School of Medicine, 420 Delaware Street S.E., Minneapolis, MN 55455, USA

4 Department of Pathology and Laboratory Medicine, Hospital Pathology Associates, 2800 10th Avenue South, Suite 2200, Minneapolis, MN 55407, USA
RCs due to decreased expression of 3BHSD. Calretinin is decreased in testicular adrenal-like tumors and absent in normal adrenocortical cells, which explain why they lack RCs. Calretinin expression in androgen-producing cells is independent from androgen receptors and androgen synthesis. RCs represent for the most part, if not exclusively, crystallized forms of a 3BHSD/calretinin complex. Androgen-producing cells containing and lacking RCs differ mainly in the level of expression of these proteins and androgen receptors.

Keywords Reinke crystals · Leydig cell · Adrenal rest tumor . Gonadal steroid hormones $\cdot$ Immunohistochemistry

\section{Introduction}

In a recent study, we showed that Reinke crystals (RCs) are invariably present in a subset of Leydig cells from a normal testis, that the crystals dissolve rapidly in formalin fixative and slowly in alcohol, and that they stain specifically with antibodies against $3 \beta$-hydroxysteroid dehydrogenase (3BHSD). Contrary to previous assertions, RCs lack expression of nestin and are not products of degradation [1-3]. We have now studied neoplastic and non-neoplastic examples of androgenproducing cells known to harbor or lack RCs. The goal of this study was to determine if consistent immunophenotypic differences exist between these morphologically and biologically closely related subgroups and if these differences provide further insight on the nature of RCs.

\section{Materials and methods}

The pathology databases from five hospitals affiliated with the University of Minnesota Medical School were searched for 
Table 1 Clinicopathologic features

\begin{tabular}{|c|c|c|c|c|c|c|c|c|c|}
\hline \multirow{2}{*}{$\begin{array}{l}\text { No. } \\
1\end{array}$} & \multirow{2}{*}{$\begin{array}{l}\text { DX } \\
\text { LCT }\end{array}$} & \multirow{2}{*}{$\begin{array}{l}\text { Age } \\
33\end{array}$} & \multirow{2}{*}{$\begin{array}{l}\text { Size cm } \\
0.1\end{array}$} & \multirow{2}{*}{$\begin{array}{l}\text { Met/Rec } \\
\text { N/A }\end{array}$} & \multirow{2}{*}{$\begin{array}{l}\text { FU-Mo } \\
\text { N/A }\end{array}$} & \multirow{2}{*}{$\begin{array}{l}\text { Presenting symptom } \\
\text { Seminoma }\end{array}$} & \multicolumn{2}{|c|}{ Crystals LC LCT } & \multirow{2}{*}{$\begin{array}{l}\begin{array}{l}\text { Mitoses } \\
(10 \mathrm{HPF})\end{array} \\
0\end{array}$} \\
\hline & & & & & & & +++ & + & \\
\hline 2 & LCT & 38 & 0.1 & No & 30 & Incidental & +++ & ++ & 0 \\
\hline 3 & LCT & 76 & 0.3 & No & 151.4 & Incidental & +++ & ++ & 0 \\
\hline 4 & LCT & 46 & 0.2 & No & 239.8 & Incidental & +++ & ++ & 0 \\
\hline 5 & LCT & 37 & 1.5 & No & 46.0 & Gynecomastia & +++ & +++ & 3 \\
\hline 6 & LCT & 42 & 2.2 & No & 110.8 & Pain & +++ & +++ & 0 \\
\hline 7 & LCT & 45 & 0.8 & No & 8.5 & Pain & +++ & +++ & 0 \\
\hline 8 & LCT & 68 & 0.5 & No & 15.8 & Incidental & +++ & +++ & 0 \\
\hline 9 & LCT & 56 & 1.7 & No & 149.7 & Incidental & N/A & +++ & 0 \\
\hline 10 & LCT & 68 & 0.7 & No & 78.7 & Pain & N/A & +++ & 1 \\
\hline 11 & LCT & 63 & 1.2 & No & 11.4 & Incidental & +++ & +++ & 0 \\
\hline 12 & LCT & 65 & 1.2 & No & 18.4 & Incidental & N/A & +++ & 0 \\
\hline 13 & LCT & 38 & 3.4 & No & 46.0 & N/A & N/A & +++ & 1 \\
\hline 14 & LCT & 56 & 1.4 & No & 13.3 & N/A & ++ & +++ & 0 \\
\hline 15 & LCT & 40 & 0.7 & N/A & N/A & Pain & ++ & + & 0 \\
\hline 16 & LCT & 49 & 0.7 & No & 32.0 & Pain & ++ & ++ & 0 \\
\hline 17 & LCT & 44 & 0.6 & N/A & N/A & N/A & + & + & 0 \\
\hline 18 & LCT & 50 & 1.8 & No & 29.2 & Incidental & +++ & + & 0 \\
\hline 19 & ALCT & 43 & 0.8 & No & 76.6 & Incidental & +++ & - & 0 \\
\hline 20 & ALCT & 66 & 4.2 & No & 4.2 & Mass & +++ & - & 1 \\
\hline 21 & TART & 30 & 0.4 & No & 30.0 & Incidental & +++ & - & 0 \\
\hline 22 & TART-L & 48 & 1.0 & N/A & N/A & Incidental & + & - & 0 \\
\hline 23 & TTAGS & 30 & 3.5 & N/A & N/A & Infertility & N/A & - & 1 \\
\hline 24 & TTAGS & 6 & 1.2 & N/A & N/A & Precocious puberty & N/A & - & 0 \\
\hline 25 & AIS & 17 & No tumor & N/A & N/A & Amenorrhea & - & N/A & N/A \\
\hline 26 & AIS & 15 & No tumor & N/A & N/A & Amenorrhea & - & N/A & N/A \\
\hline
\end{tabular}

Scoring: - (absent), + (scant), ++ (moderate), and +++ (abundant)

$D X$ diagnosis, Met/Rec metastases/recurrence, $F U$-Mo follow-up in months, HPF high-power field, $L C$ non-tumoral Leydig cells, $L C T$ Leydig cell tumor, ALCT atypical Leydig cell tumor, TART testicular adrenal rest tumor, TART-L TART with lipomatous component, TTAGS testicular tumor of adrenogenital syndrome, AIS androgen insensitivity syndrome. N/A not available/not applicable

cases with testicular sex cord-stromal cell tumors (SCSCTs), testicular specimens from cases with androgen insensitivity syndrome (AIS), and cases with adrenogenital syndrome (AGS). Microscopic slides of potential study cases were reviewed. Confirmed cases with available paraffinembedded blocks were included in the study. Participating institutions use $10 \%$ buffered formalin for tissue fixation. Sertoli cell lesions were excluded from the analysis. The lesions were subclassified using the current World Health Organization and Armed Forces Institute of Pathology classifications [4,5]. The number of RCs per slide was semiquantified as follows: absent, scant (less than 5), moderate (5 to 20), and abundant (>20). Crystals were semiquantified separately in tumoral and non-tumoral entities. Immunohistochemical studies included cytokeratin cocktail (CK) (AE1/AE3+8/18 cocktail, Biocare Medical, catalog \# CM162B, Concord CA; dilution 1:900), epithelial membrane antigen (EMA) (Cell Marque, catalog \# 247M-95, Rocklin, CA; dilution 1:1000), inhibin A (Novacastra, catalog \# NCLL-Inhibin A, Newcastle upon Tyne, UK; dilution 1:1500), calretinin (Novacastra, catalog \# NCL-L-CALRET-566, Newcastle upon Tyne, UK; dilution 1:1200), CD117 (Cell Marque, catalog \# 117R-14, Rocklin, CA; dilution 1:300), synaptophysin (Novacastra, catalog \# NCL-SYNAP-299,
Newcastle upon Tyne, UK; dilution 1:100), CD56 (Biocare Medical, Concord, CA; catalog \# CD164A, dilution 1:100), vimentin (Cell Marque, Rocklin, CA; catalog \# 347M-14, dilution 1:250), S100 (Novacastra, catalog \# CL-L-S100P, Newcastle upon Tyne, UK; dilution 1:1600), testosterone (GeneTex, Irvine, CA; product \# GTX72779; dilution, 1:125), androstenedione (ASD) (US Biological, Salem, MA; product \# 151581; dilution, 1:100), dehydroepiandrosterone (DHEA) (US Biological; product \# 140041; dilution, 1:50), 3BHSD (Santa Cruz Biotechnology, Dallas, TX; product \# sc100466; dilution, 1:250), 17 $\alpha$-hydroxylase/17,20-lyase (CYP17A1) (Santa Cruz Biotechnology; product \# sc46084; Dallas, TX; dilution 1:110), 17 $\beta$-hydroxysteroid dehydrogenase (17BHSD) (Abcam Inc., Boston, MA; [EP1682Y] ab51045; dilution, 1:50), androgen receptor (Bio SB, Santa Barbara, CA, catalog \# BSB 6074), PAX2 (Bio SB, Santa Barbara, CA, catalog \# BSB 2566, pre-dilute), and PAX8 (Cell Marque, Rocklin, CA; catalog \# 363M-14, predilute). Immunohistochemistry was performed on a Leica BOND-III automated stainer (Leica Biosystems, Melbourne, Australia) using citrate and EDTA buffer antigen retrieval protocols. Dilutions and retrieval methods were optimized in preliminary studies. The full immunohistochemical panel was performed in 17 testes with SCSCTs, 11 of these had lesions 
included in this study; in the remaining six cases which contained Sertoli cell lesions, only the non-neoplastic cells were evaluated. The panel was also applied to 10 nontumoral adrenal glands from radical nephrectomy cases. A second panel selected because of its discriminative diagnostic power was applied to all 26 study lesions and 10 non-tumoral adrenal glands. The second panel included androgenic hormones, enzymes, and receptors, as well as calretinin, inhibin, and cytokeratin cocktail. For the evaluation of the immunohistochemical stains, a numerical system for grading the intensity of expression was used $(1=$ weak, $2=$ moderate, and 3 = strong), relative to the strongest and negative internal control cells in each preparation. In cases with partial expression of a marker, the percentage of positive cells was recorded. All parameters were evaluated in tumoral and non-tumoral androgen-producing cells present on each study slide. Electronic medical records of identified cases were reviewed for retrieving demographic data, after approval from the respective institutional review boards from the participating institutions.

\section{Results}

\section{Clinicopathologic features}

The clinicopathologic features are summarized in Table 1. Twenty-six cases met the inclusion criteria: 20 with Leydig cell tumors (LCTs), 2 with testicular adrenal rest tumors
(TARTs), 2 with testicular tumors of adrenogenital syndrome (TTAGS), and 2 with AIS. Two of the LCT cases showed atypical morphology: one showed extensive myxoid and/or clear cell change and one showed prominent myxoid change and cystic degeneration. One of the TART cases showed a prominent lipomatous component (adrenolipoma). None of the cases showed histologic features associated with malignancy. Segregated by diagnostic categories, the mean age at diagnosis for LCT was 50 years (range 30-76), TART 39 (range 30-48), TTAGS 18 (range 6-30), and AIS 16 (range 15-17). The mean size of LCT was $1.2 \mathrm{~cm}$ (range $0.1-4.2$ ), TART $0.7 \mathrm{~cm}$ (range 0.4-1), and TTAGS $2.4 \mathrm{~cm}$ (range 1.2-3.5). Follow-up (FU) was available in $69 \%(18 / 26)$ of the cases, and the mean FU time was 60.7 months (range 4.2-239.8); none of the cases developed recurrences or metastases. Among the LCT cases with available clinical information, $63 \%(12 / 19)$ were discovered incidentally and $26 \%$ (5/19) consulted for pain, one for a testicular mass, and one for gynecomastia. The TART cases were found incidentally. In the TTAGS group, the presenting symptoms were precocious puberty and infertility, and in the AIS group, the presenting symptom was primary amenorrhea.

\section{Immunohistochemical studies}

Table 2 summarizes the results of a panel of markers commonly utilized in the work-up of SCSCT performed in a

Table 2 Panel 1: markers commonly used in sex cord-stromal tumors

\begin{tabular}{|c|c|c|c|c|c|c|c|}
\hline \multirow[t]{2}{*}{$\mathrm{IHC}$} & \multirow[t]{2}{*}{$\mathrm{LC}(n=17)$} & \multirow[t]{2}{*}{$\operatorname{LCT}(n=9)$} & \multirow[t]{2}{*}{ TART $(n=1)$} & \multirow[t]{2}{*}{ TTAGS $(n=1)$} & \multicolumn{3}{|c|}{ Adrenal cortex $(n=10)$} \\
\hline & & & & & Zona reticularis & Zona fasciculata & Zona glomerulosa \\
\hline Vimentin & $\begin{array}{l}\text { Positive } \\
\text { Intensity = 1-3 }\end{array}$ & $\begin{array}{l}\text { Positive } \\
\text { Intensity }=2-3\end{array}$ & $\begin{array}{l}\text { Variable } \\
5 \% \\
\text { Intensity = } 1\end{array}$ & $\begin{array}{l}\text { Positive } \\
\text { Intensity }=1-2\end{array}$ & Negative & Negative & $\begin{array}{l}\text { Positive } \\
\text { Intensity }=1-3\end{array}$ \\
\hline S100 & $\begin{array}{l}\text { Variable }=2 / 17 \\
0-50 \% \\
\text { Intensity }=1\end{array}$ & Negative & Negative & Negative & Negative & Negative & Negative \\
\hline EMA & Negative & Negative & Negative & Negative & Negative & Negative & Negative \\
\hline Synaptophysin & $\begin{array}{l}\text { Variable }=4 / 17 \\
0-60 \% \\
\text { Intensity }=1\end{array}$ & $\begin{array}{l}\text { Variable = } 3 / 9 \\
\text { Rare cells } \\
\text { Intensity = } 1\end{array}$ & $\begin{array}{l}\text { Variable } \\
0-10 \% \\
\text { Intensity = } 1\end{array}$ & $\begin{array}{l}\text { Rare cells } \\
\text { Intensity = } 1\end{array}$ & $\begin{array}{l}\text { Variable } \\
0-10 \% \\
\text { Intensity = } 1\end{array}$ & $\begin{array}{l}\text { Variable } \\
0-10 \% \\
\text { Intensity = } 1\end{array}$ & $\begin{array}{l}\text { Variable } \\
0-20 \% \\
\text { Intensity = } 1\end{array}$ \\
\hline C-Kit & Negative & $\begin{array}{l}\text { Variable = } 1 / 9 \\
0-40 \% \\
\text { Intensity }=1\end{array}$ & Negative & Negative & Negative & Negative & Negative \\
\hline CD56 & $\begin{array}{l}\text { Positive } \\
\text { Intensity }=2-3\end{array}$ & $\begin{array}{l}\text { Positive } \\
\text { Intensity }=1-3\end{array}$ & $\begin{array}{l}\text { Positive } \\
\text { Intensity }=1-3\end{array}$ & $\begin{array}{l}\text { Positive } \\
\text { Intensity = 1-3 }\end{array}$ & Negative & $\begin{array}{l}\text { Variable } \\
10-30 \% \\
\text { Intensity = } 1-2\end{array}$ & $\begin{array}{l}\text { Positive } \\
\text { Intensity }=3\end{array}$ \\
\hline PAX2/PAX8 & Negative & Negative & Negative & Negative & Negative & Negative & Negative \\
\hline
\end{tabular}

$n=$ number of cases; scoring: 1 (weak), 2 (moderate), and 3 (strong)

LC normal Leydig cells, LCT Leydig cell tumor, TART testicular adrenal rest tumor, TTAGS testicular tumor of adrenogenital syndrome, EMA epithelial membrane antigen 
subset of the cases and Table 3 the expanded endocrine panel performed in all cases. Inhibin is consistently and strongly positive in normal Leydig cells, Leydig cells from AIS (LC-AIS), LCTs, TTAGS, and TARTs. In the adrenal cortex, inhibin is variably expressed only in the androgen-producing zona reticularis. Vimentin expression is strong in normal Leydig cells, LCTs, and LC-AIS; it is weak to moderate in TTAGS and TARTs. In the adrenal cortex, vimentin is negative in the zonas reticularis and fasciculata; it is patchy, with variable intensity in the zona glomerulosa. Calretinin is strongly positive in normal Leydig cells, LCTs, and LC-AIS; its expression is markedly decreased or absent in TTAGS and TARTs and is absent in normal adrenocortical cells (Fig. 1). CD56 is

Table 3 Panel 2: panel for androgen-producing cells

\begin{tabular}{|c|c|c|c|c|c|c|c|c|}
\hline \multirow[t]{2}{*}{ IHC } & \multirow[t]{2}{*}{$\mathrm{LC}(n=17)$} & \multirow[t]{2}{*}{ LC-AIS $(n=2)$} & \multirow[t]{2}{*}{$\operatorname{LCT}(n=18)$} & \multirow{2}{*}{$\begin{array}{l}\text { TART } \\
(n=2)\end{array}$} & \multirow{2}{*}{$\begin{array}{l}\text { TTAGS } \\
(n=2)\end{array}$} & \multicolumn{3}{|c|}{ Adrenal cortex $(n=10)$} \\
\hline & & & & & & $\begin{array}{l}\text { Zona } \\
\text { reticularis }\end{array}$ & $\begin{array}{l}\text { Zona } \\
\text { fasciculata }\end{array}$ & $\begin{array}{l}\text { Zona } \\
\text { glomerulosa }\end{array}$ \\
\hline Testosterone & $\begin{array}{l}\text { Positive } \\
\text { Intensity }=1- \\
\quad 3\end{array}$ & $\begin{array}{l}\text { Positive } \\
\text { Intensity = } 3\end{array}$ & $\begin{array}{l}\text { Variable = 8/ } \\
\quad 18 \\
0-100 \% \\
\text { Intensity = 1- } \\
\quad 3\end{array}$ & $\begin{array}{l}\text { Positive } \\
\text { Intensity = } \\
\quad 1-3\end{array}$ & $\begin{array}{l}\text { Positive } \\
\text { Intensity = } \\
\quad 1-3\end{array}$ & $\begin{array}{l}\text { Positive } \\
\text { Intensity }=1- \\
\quad 3\end{array}$ & Negative & Negative \\
\hline DHEA & $\begin{array}{l}\text { Positive } \\
\text { Intensity }=2- \\
\quad 3\end{array}$ & $\begin{array}{l}\text { Positive } \\
\text { Intensity = } 3\end{array}$ & $\begin{array}{l}\text { Variable = } 7 / \\
\quad 18 \\
0-100 \% \\
\text { Intensity = 1- } \\
\quad 3\end{array}$ & $\begin{array}{l}\text { Positive } \\
\text { Intensity = } \\
\quad 1-3\end{array}$ & $\begin{array}{l}\text { Positive } \\
\text { Intensity = } \\
1-3\end{array}$ & $\begin{array}{l}\text { Positive } \\
\text { Intensity }=1- \\
\quad 3\end{array}$ & Negative & Negative \\
\hline ASD & $\begin{array}{l}\text { Variable = 15/ } \\
\quad 17 \\
0-100 \% \\
\text { Intensity = } 1- \\
\quad 3\end{array}$ & $\begin{array}{l}\text { Positive } \\
\text { Intensity = } 3\end{array}$ & $\begin{array}{l}\text { Variable }=2 / \\
\quad 18 \\
0-100 \% \\
\text { Intensity = } 1- \\
\quad 3\end{array}$ & $\begin{array}{l}\text { Positive } \\
\text { Intensity = } \\
\quad 1-3\end{array}$ & $\begin{array}{l}\text { Positive } \\
\text { Intensity = } \\
\quad 1-3\end{array}$ & Negative & Negative & Negative \\
\hline 3BHSD & $\begin{array}{l}\text { Positive } \\
\text { Intensity }=2- \\
\quad 3\end{array}$ & $\begin{array}{l}\text { Positive } \\
\text { Intensity = } 1\end{array}$ & $\begin{array}{l}\text { Positive } \\
\text { Intensity }=1- \\
\quad 3\end{array}$ & $\begin{array}{l}\text { Positive } \\
\text { Intensity = } 1\end{array}$ & $\begin{array}{l}\text { Positive } \\
\text { Intensity = } \\
\quad 1-2\end{array}$ & $\begin{array}{l}\text { Positive } \\
\text { Intensity }=2- \\
\quad 3\end{array}$ & $\begin{array}{l}\text { Positive } \\
\text { Intensity }=2- \\
\quad 3\end{array}$ & $\begin{array}{l}\text { Positive } \\
\text { Intensity }=2-3\end{array}$ \\
\hline CYP17A1 & $\begin{array}{l}\text { Positive } \\
\text { Intensity = } 3\end{array}$ & $\begin{array}{l}\text { Positive } \\
\text { Intensity = } 1\end{array}$ & $\begin{array}{l}\text { Positive } \\
\text { Intensity }=1- \\
\quad 3\end{array}$ & $\begin{array}{l}\text { Positive } \\
\text { Intensity }=3\end{array}$ & $\begin{array}{l}\text { Positive } \\
\text { Intensity = } 3\end{array}$ & $\begin{array}{l}\text { Positive } \\
\text { Intensity }=3\end{array}$ & $\begin{array}{l}\text { Positive } \\
\text { Intensity = } 3\end{array}$ & Negative \\
\hline 17BHSD & $\begin{array}{l}\text { Variable }=15 / \\
\quad 17 \\
0-30 \% \\
\text { Intensity }=1- \\
\quad 3\end{array}$ & Negative & $\begin{array}{l}\text { Variable }=13 / \\
\quad 18 \\
0-100 \% \\
\text { Intensity = } 1- \\
\quad 3\end{array}$ & $\begin{array}{l}\text { Variable } \\
50-100 \% \\
\text { Intensity = } \\
\quad 1-3\end{array}$ & Negative & Negative & Negative & Negative \\
\hline $\begin{array}{l}\text { Androgen } \\
\text { receptor }\end{array}$ & $\begin{array}{l}\text { Positive } \\
\text { Intensity = } 2\end{array}$ & Negative & $\begin{array}{l}\text { Positive } \\
\text { Intensity = } 2\end{array}$ & $\begin{array}{l}\text { Variable } \\
10 \% \\
\text { Intensity = } 1\end{array}$ & $\begin{array}{l}\text { Variable }=1 / \\
2 \\
0-60 \% \\
\text { Intensity }=1\end{array}$ & Negative & $\begin{array}{l}\text { Rare cells } \\
\text { Intensity = } 1\end{array}$ & $\begin{array}{l}\text { Variable } \\
20 \% \\
\text { Intensity = } 1\end{array}$ \\
\hline Calretinin & $\begin{array}{l}\text { Positive } \\
\text { Intensity }=3\end{array}$ & $\begin{array}{l}\text { Positive } \\
\text { Intensity }=2-3\end{array}$ & $\begin{array}{l}\text { Positive } \\
\text { Intensity }=2- \\
\quad 3\end{array}$ & $\begin{array}{l}\text { Variable } \\
1 / 2 \\
0-100 \% \\
\text { Intensity = } \\
\quad 1-2\end{array}$ & $\begin{array}{l}\text { Variable } \\
1 / 2 \\
0-100 \% \\
\text { Intensity = } 1\end{array}$ & Negative & Negative & Negative \\
\hline Inhibin & $\begin{array}{l}\text { Positive } \\
\text { Intensity = } 3\end{array}$ & $\begin{array}{l}\text { Positive Intensity }= \\
\quad 2-3\end{array}$ & $\begin{array}{l}\text { Positive } \\
\text { Intensity }=2- \\
\quad 3\end{array}$ & $\begin{array}{l}\text { Positive } \\
\text { Intensity }=3\end{array}$ & $\begin{array}{l}\text { Positive } \\
\text { Intensity = } 3\end{array}$ & $\begin{array}{l}\text { Positive } \\
\text { Intensity }=1- \\
\quad 3\end{array}$ & Negative & Negative \\
\hline Pankeratin & $\begin{array}{l}\text { Variable } \\
4 / 17 \\
0-100 \% \\
\text { Intensity = } 1- \\
\quad 3\end{array}$ & $\begin{array}{l}\text { Rare cells } \\
\text { Intensity = } 1\end{array}$ & $\begin{array}{l}\text { Rare cells } \\
\text { Intensity = 1- } \\
\quad 3\end{array}$ & Negative & $\begin{array}{l}\text { Rare cells } \\
\text { Intensity = } \\
\quad 1-3\end{array}$ & $\begin{array}{l}\text { Rare cells } \\
\text { Intensity }=1- \\
\quad 3\end{array}$ & $\begin{array}{l}\text { Rare cells } \\
\text { Intensity }=1- \\
\quad 3\end{array}$ & $\begin{array}{l}\text { Rare cells } \\
\text { Intensity }=1-3\end{array}$ \\
\hline
\end{tabular}

$n=$ number of cases; scoring: 1 (weak), 2 (moderate), and 3 (strong)

DHEA dehydroepiandrosterone, ASD androstenedione, 3BHSD 3 $\beta$-hydroxysteroid dehydrogenase, CYP17A1 cytochrome P450 17A1, 17BHSD 17ßhydroxysteroid dehydrogenase, $L C$ normal Leydig cells, $L C$-AIS Leydig cells from androgen insensitivity syndrome, $L C T$ Leydig cell tumor, TART testicular adrenal rest tumor, TTAGS testicular tumor of adrenogenital syndrome 

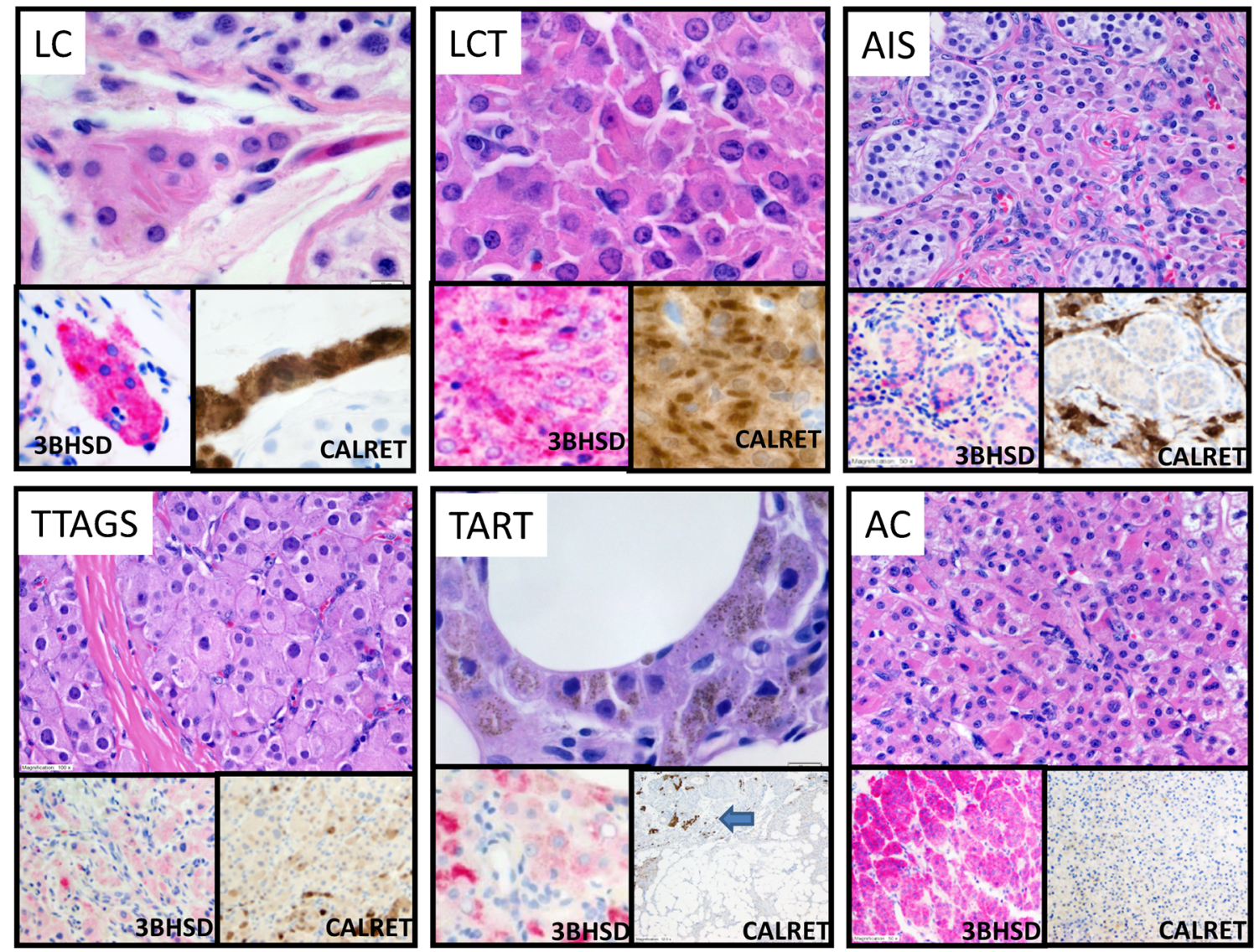

Fig. 1 Expression of 3BHSD and calretinin in steroid-producing cells. $3 B H S D 3 \beta$-hydroxysteroid dehydrogenase, $L C$ Leydig cell, $L C T$ Leydig cell tumor, AIS androgen insensitivity syndrome, TTAG $S$ testicular tumor of adrenogenital syndrome, TART testicular adrenal rest tumor, $A C$ adrenal cortex, SC Sertoli cell. LC and LCT are the only cells with Reinke

positive in normal Leydig cells, LCTs, LC-AIS, TTAGS, and TARTs. In adrenocortical cells, CD56 expression is strong in the zona glomerulosa, moderate in the exterior layers of the zona fasciculata, and negative in the internal zona fasciculata and zona reticularis. Pankeratin was diffuse and strong in one of the LCT cases with atypical morphology. In normal Leydig cells, LCTs, LC-AIS, TTAGS, and TARTs, pankeratin expression is nonuniform and highly variable. In the adrenal cortex, pankeratin expression is also non-uniform and highly variable, being more common in the zona glomerulosa, followed by the zonas reticularis and fasciculata. S100 showed partial weak reactivity in normal Leydig cells in a few cases (2/17), but it was negative in the remaining normal Leydig cells, LCTs, LC-AIS, TTAGS, TARTs, and adrenal cortex cells. Synaptophysin showed focal weak staining in a small subset of cells in all the study groups. $\mathrm{C}$-Kit showed weak partial staining in one of the atypical LCT cases, but it was negative in all the remaining groups. EMA, chromogranin, PAX2, and PAX8 were consistently negative in normal Leydig cells, LCTs, LC-AIS, TTAGS, TARTs, and adrenocortical cells. crystals and strong coexpression of both markers. LCs from AIS show decreased 3BHSD (no difference between LC and SC) but preserved calretinin. TART, TTAGS, and AC show minimal or absent expression of calretinin; the TART case shows preserved calretinin expression in extratumoral LC (arrow)

\section{Endocrine profile}

Figure 2 and Table 3 summarize the results of these studies. Normal Leydig cells, LC-AIS, TARTs, and TTAGS show consistent expression of testosterone and DHEA, and variable ASD. Most LCTs have no or decreased expression of the three hormones. In the adrenal cortex, only the zona reticularis is positive for testosterone and DHEA but negative for ASD. Normal Leydig cells, LCTs, and all layers of the adrenal cortex show strong and consistent expression of 3BHSD; by contrast, expression is weak in TARTs, TTAGS, and LC-AIS. Expression of CYP17A1 is strong and consistent in all groups except for the zona glomerulosa of the adrenal cortex. Expression of 17BHSD is variable in normal Leydig cells, LCTs, and TARTs and negative in LC-AIS, TTAGS, and adrenocortical cells. Androgen receptors (ARs) are consistently positive in normal Leydig cells and LCTs; expression in TARTs was weak and focal $(\sim 10 \%)$. In TTAGS, the younger patient (age 6) had a complete loss of AR expression, while the older patient (age 30) retained weak expression in $~ 60 \%$ of the cells. In the adrenal cortex, a small subset of cells in the zona glomerulosa $(\sim 20 \%)$ and in the zona fasciculata $(\sim 5 \%)$ 


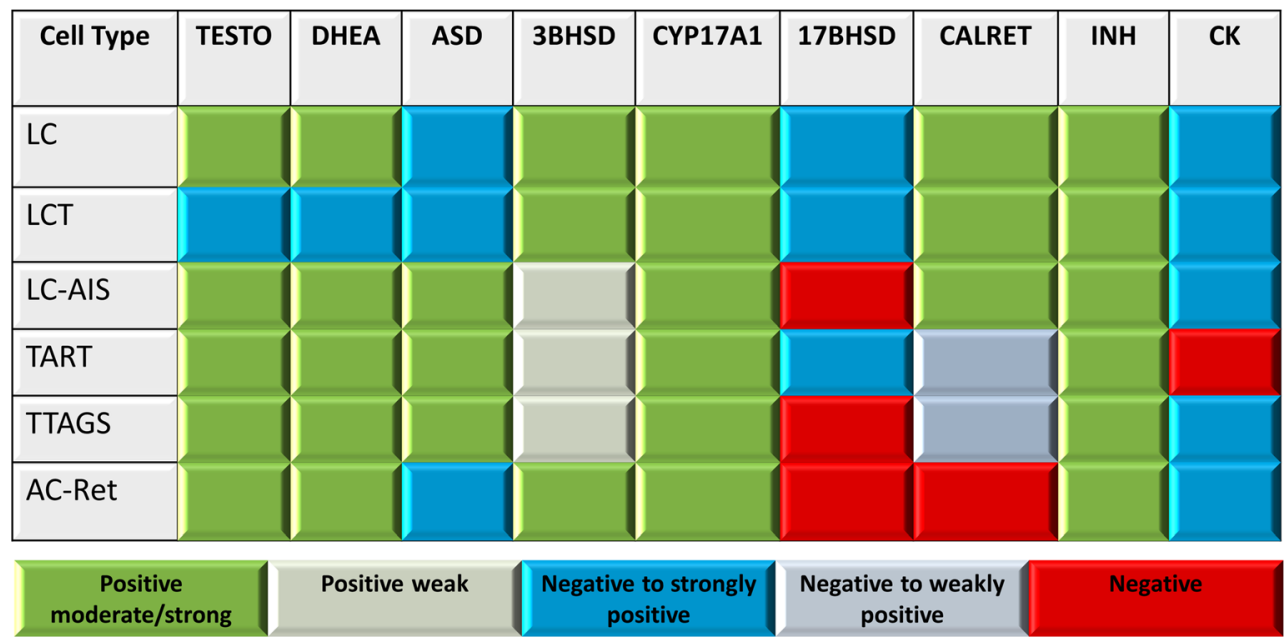

Fig. 2 Endocrine profile of steroid-producing cells and visual scale of level of expression. TESTO testosterone, DHEA dehydroepiandrosterone, $A S D$ androstenedione, $3 B H S D$ 3 $\beta$-hydroxysteroid dehydrogenase, CYP17A1 cytochrome P450 17A1, 17BHSD 17 $\beta$-hydroxysteroid dehydrogenase, CALRET calretinin, INH inhibin, $C K$ cytokeratin cocktail, $L C$ Leydig cell, $L C T$ Leydig cell tumor, $A I S$ androgen insensitivity

show weak AR expression, but the androgen-producing zona reticularis was negative.

\section{Reinke crystals}

RCs were identified in 18/20 (90\%) LCT cases; RCs were not observed in the two cases with atypical morphology. RCs were abundant in 10, moderate in four, and scant in four cases. Non-tumoral Leydig cells were present in adjacent testicular tissue in 16/20 of the specimens with LCTs, and RCs were identified in all cases (100\%): 12 abundant, 3 moderate, and 1 scant. RCs were present in the non-tumoral Leydig cells of the two cases of TART. The two cases of TTAGS did not have normal Leydig cells for evaluation. Crystals were absent in the two cases of AIS. RCs were consistently positive for calretinin and 3BHSD and negative for all the remaining markers. The staining pattern with both antibodies was grumous and discontinuous. Because on immunostained slides the crystals were frequently obscured by cytoplasmic staining, we performed several dilutions and combinations of calretinin and 3BHSD antibodies to improve the crystal to cytoplasmic contrast with success (Fig. 3); however, the crystals continued to appear as grumous sausage-shaped formations instead of the crisp elegant structures observed on hematoxylin and eosin.

\section{Discussion}

RCs, originally described in 1896, are unique to Leydig cells and LCTs and help separate them from their close relatives TARTs, TTAGS, and adrenal cortex cells. We recently clarified several misconceptions about RCs: we demonstrated that syndrome, TART testicular adrenal rest tumor, AC-Ret adrenal cortex, zona reticularis. LCTs have decreased expression of androgens compared to the other groups. LC and LCT are the only groups showing strong coexpression of 3BHSD and calretinin. LC-AIS show weak 3BHSD expression but strong calretinin. TART, TTAGS, and AC-Ret have weak or negative expression of calretinin

RCs are almost invariably present in a subset of Leydig cells in normal testes as originally described by Friedrich Reinke, but their number is variable; we showed that RCs are amphiphilic: they dissolve rapidly in formalin and slowly in alcohol; we demonstrated that RCs stain specifically with antibodies against 3BHSD and disproved the previous assertion that the crystals are positive for nestin, and finally, we demonstrated that they do not represent waste/degenerative products as previously reported $[2,3]$. Embryologically, the SCSCs of the gonads and the adrenal cortex share a common origin from the cells of the adrenogenital primordium [6]. This explains the close immunomorphologic resemblance between all these cell groups [7]. While Sertoli cells develop highly specialized functions directed at providing an optimal environment for regulation of spermatogenesis [6-8], Leydig cells, testicular adrenal-like cells, and adrenocortical cells remain to be primary endocrine/paracrine cells [9]. In the current study, we found RCs in all cases containing normal Leydig cells and in $90 \%$ of LCT cases, a percentage that is much higher than the one third of cases described in reference books $[4,5]$. This discrepancy may be explained by fixation times and the time and effort dedicated to this task. By immunohistochemistry, in addition to $3 \mathrm{BHSD}, \mathrm{RC}$ are also positive for calretinin. Among steroid-producing cells, the main difference between cells containing and lacking RCs was the level of coexpression of 3BHSD and calretinin. Strong coexpression of both proteins was unique to normal Leydig cells and LCTs. Figure 1 shows the different expression levels of 3BHSD and calretinin in all the study groups. Our results indicate that RCs represent for the most part, if not exclusively, crystallized forms of a 3BHSD/calretinin complex. RCs did not contain androgens; however, given the hydrosoluble properties of the crystals, it is 
Fig. 3 Reinke crystals in normal Leydig cells. a Calretinin, 1:1200 dilution. b $3 \beta$-Hydroxysteroid dehydrogenase (3BHSD), 1:250 dilution. c Combined calretinin/ 3BHSD, 1:1800/1:300 dilutions. d Combined calretinin/3BHSD, 1:1800/1:250 dilutions. The crystals stain strongly with calretinin and variably with $3 \mathrm{BHSD}$. The combination of both diluted antibodies improves the contrast with the cytoplasm; however, the grumous pattern of staining persists

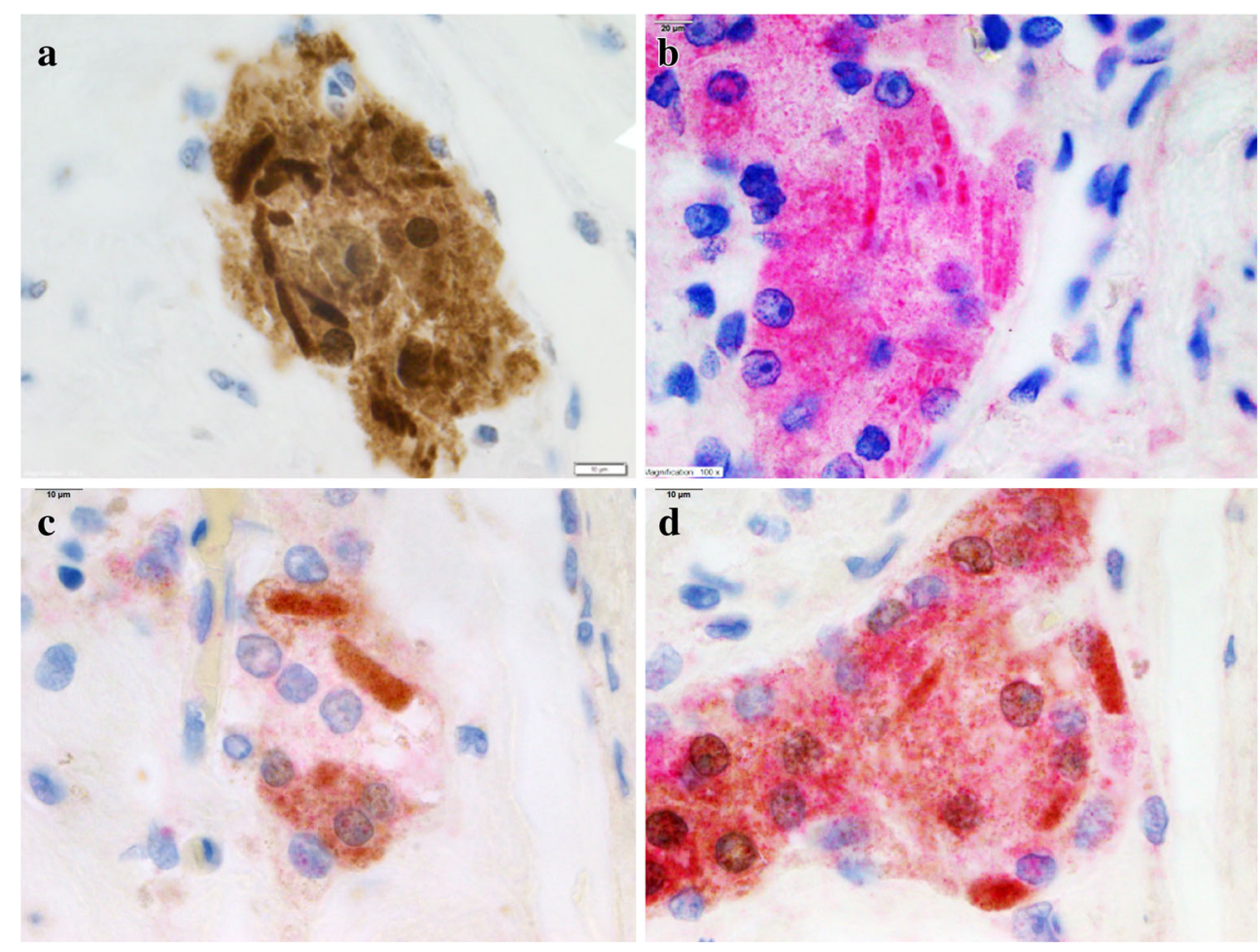

possible that the presence of lipophilic hormones in the cytoplasm may be necessary or contributes to the crystallization process. Leydig cells from AIS cases express high calretinin but low 3BHSD, TTAGS and TARTs show decreased expression of both 3BHSD and calretinin, and adrenocortical cells show high 3BHSD but absent calretinin, while the expression of androgens is maintained in all these groups. All these groups lack RCs, suggesting that a high concentration of both proteins is necessary for the crystallization process. The rare cases of adrenal neoplasms containing RCs [10] can probably be explained by the frequent aberrant expression of calretinin by adrenal neoplasms [11], which is not present in normal adrenocortical cells. If concurrent high coexpression level of $3 \mathrm{BHSD} /$ calretinin occurs in any given steroid-producing tumor, crystallization may happen. Crystalline structures resembling RCs were observed by Magalhães in periendothelial spindle cells in the adrenal gland of two thirds of patients who underwent adrenalectomy for Buerger's disease [12]. The crystals were absent on the histologic preparations and were only identified by electron microscopy. These spindle cells lacked the ultrastructural features of adrenocortical cells and resembled fibroblasts. In our study, we did not identify any population of spindle cells coexpressing 3BHSD/ calretinin in the 10 studied normal adrenal glands. Despite their intra-abdominal location, Leydig cells from AIS cases lack RCs, and this dispels the notion that formation of RCs is caused by an increased core body temperature [3]. The lack of ARs in LC-AIS correlated with markedly reduced expression of 3BHSD but did not affect calretinin. This indicates that under physiologic conditions, ARs either upregulate or prevent the downregulation of 3 BHSD but do not affect calretinin. Calretinin is not present in androgen-producing adrenal cortex cells, indicating that it does not participate in androgen synthesis and that it is independent from adrenocorticotropic hormone receptor (ACTH-R). The origin of testicular adrenal rest tumors, TARTs, and TTAGS is not clear; it has been hypothesized that they represent ectopic adrenal tissue or that they arise from pluripotent perivascular cells; however, experimental support is lacking [13-16]. Our work shows that TARTs and TTAGS show a unique phenotype between Leydig cells and androgen-producing adrenocortical cells. All these groups show similar expression of inhibin and androgens; however, TARTs/TTAGS show reduced expression of 3BHSD compared to Leydig and adrenocortical cells, and the expression of calretinin and androgen receptors is intermediate between Leydig and adrenocortical cells, in which these proteins are either strongly expressed or negative, respectively. In contrast to what has been previously reported, synaptophysin and CD56 immunostains lacked a discriminative power for separating testicular adrenal-like lesions from LCTs; expression of CD56 is consistent in both lesions, while expression of synaptophysin is erratic [13-15]. We tried to determine if differences in the expression of ACTH-Rs exist between LCs, testicular adrenal-like lesions, and adrenocortical cells as suggested by the pathophysiology of adrenogenital syndrome; however, after testing several commercially available antibodies, we did not find one with adequate specificity for performing these studies. Finally, LCTs compared to 
normal Leydig cells and testicular adrenal-like lesions showed decreased expression of androgens. It is not clear if this is the result of decreased production, decreased cytoplasmic storage, or increased secretion of these hormones.

\section{Conclusions}

We found RCs in $90 \%$ of LCT cases, a percentage that is much higher than what has been described in reference books. We also demonstrated consistent immuno phenotypic differences between the different groups of normal and neoplastic androgen-producing cells and between androgen-producing cells containing and lacking RCs. The main differences among these groups were in the level of expression of 3BHSD, calretinin, and AR. We found that RCs stain specifically for 3BHSD and calretinin, indicating that they represent crystallized forms of a $3 \mathrm{BHSD} /$ calretinin complex. The main difference between androgen-producing cells containing or lacking RCs is the level of expression of these two proteins; crystals are only present in cells with strong concomitant expression of both proteins, a feature unique to Leydig cells and LCTs. Our findings clarify previously unknown aspects of normal and neoplastic androgen-producing cell groups with overlapping morphologic and biological features and the composition of Reinke crystals. It would have been important to determine if differences in expression of ACTH-Rs exist between these cell groups; unfortunately, we were not able to find a reliable antibody for performing these studies.

Compliance with ethical standards The Institutional Review Board (IRB) of the Minneapolis VA Health Care System approved this project on 11 December 2015 (IRB \# 4615B).

Conflict of interest The authors declare that they have no conflicts of interest.

Funding There are no sources of funding to declare.

\section{References}

1. Mesa H, Gilles S, Smith S, Dachel S, Larson W, Manivel JC (2015) The mystery of the vanishing Reinke crystals. Hum Pathol 46:600-606
2. Lobo MV, Arenas MI, Alonso FJ et al (2004) Nestin, a neuroectodermal stem cell marker molecule, is expressed in Leydig cells of the human testis and in some specific cell types from human testicular tumors. Cell Tissue Res 316:369-376

3. Kozina V, Geist D, Kubinova L et al (2011) Visualization of Reinke's crystals in normal and cryptorchid testis. Histochem Cell Biol 135:215-228

4. Moch H, Humphrey PA, Ulbright TM, Reuter VE (eds) (2016) World health organization classification of tumours. Pathology and genetics of tumours of the urinary system and male genital organs, 4th edn. IARC, Lyon, pp 227-228

5. Ulbright TM, Young RH (2013) AFIP atlas of tumour pathology. Tumours of the testis and adjacent structures. Fourth series fascicle. ARP, Silver Spring, pp 271-286

6. Val P, Lefrançois-Martinez A-M, Veyssière G, Martinez A (2003) SF-1 a key player in the development and differentiation of steroidogenic tissues. Nucl Recept 1:8

7. Barrionuevo F, Burgos M, Jiménez R (2011) Origin and function of embryonic Sertoli cells. Biomol Concepts 2:537-547

8. Mruk DD, Cheng CY (2004) Sertoli-Sertoli and Sertoli-germ cell interactions and their significance in germ cell movement in the seminiferous epithelium during spermatogenesis. Endocr Rev 25: 747-806

9. DeFalcoa T, Takahashib S, Capela B (2011) Two distinct origins for Leydig cell progenitors in the fetal testis. Dev Biol 352:14-26

10. Vasiloff J, Chideckel EW, Boyd CB, Foshag LJ (1985) Testosterone-secreting adrenal adenoma containing crystalloids characteristic of Leydig cells. Am J Med 79:772-776

11. Zhang PJ, Genega EM, Tomaszewski JE, Pasha TL, LiVolsi VA (2003) The role of calretinin, inhibin, melan-A, BCL-2, and C-kit in differentiating adrenal cortical and medullary tumors: an immunohistochemical study. Mod Pathol 16:591-597

12. Magalhães MC (1972) A new crystal-containing cell in human adrenal cortex. J Cell Biol 55:126-133

13. Ashley RA, McGee SM, Isotaolo PA, Kramer SA, Cheville JC (2007) Clinical and pathological features associated with the testicular tumor of the adrenogenital syndrome. J Urol 177:546-549

14. Hassan Ali H, Samkari A, Arabi H (2013) Testicular adrenal rest "tumor" or Leydig cell tumor? A report of a challenging case with literature review. Avicenna J Med 3:15-19

15. Wang Z, Yang S, Shi H et al (2011) Histopathological and immunophenotypic features of testicular tumour of the adrenogenital syndrome. Histopathology 58:1013-1018

16. Ge RS, Dong Q, Sottas CM, Papadopoulos V, Zirkin BR, Hardy MP (2006) In search of rat stem Leydig cells: identification, isolation, and lineage-specific development. Proc Natl Acad Sci U S A 103:2719-2724

The manuscript, or parts of it, has not been and will not be submitted elsewhere for publication. The work is the result of ethically performed studies and intellectual contributions by the authors. All authors have read and approved the manuscript. All authors acknowledge the substantial participation and responsibility for this work. 